http://dx.doi.org/10.12775/szhf.2013.023

\title{
Filozofia XVII wieku jako inspiracja dla prekursorów klasycznej myśli ekonomicznej
}

Poglądy ekonomiczne Williama Petty'ego oraz Dudley’a Northa - choć często przeciwne sobie, jednakże powstałe w podobnym okresie - są przedmiotem analizy w niniejszym artykule. Rozprawy o handlu Northa stanowią niezwykle interesujące przedstawienie poglądów, charakterystycznych później dla szkoły klasycznej w ekonomii. Sformułowane w XVII wieku, na podstawie zasad Kartezjańskiej metody, pokazują, w jaki sposób filozofia epoki mogła oddziaływać na zrodzenie się oryginalnej myśli ekonomicznej. William Petty, choć w poglądach gospodarczych pozostawał merkantylistą, z nauki Bacona i Hobbesa czerpał inspirację do stworzenia statystyki - narzędzia nieocenionego dla późniejszej ekonomii.

Koncepcje Dudley’a Northa i Williama Petty'ego powstały w przełomowym dla rozwoju nauki wieku XVII. Dzięki filozofom i naukowcom położono wówczas nacisk na metody i teorie inne niż dominujący w scholastycznym średniowieczu arystotelizm. Rewolucja naukowa XVI i XVII wieku

dokonała się dzięki ludziom stawiającym pytania, na które można znaleźć odpowiedź w drodze eksperymentu, [...] koncentrującym uwagę na dokładnej obserwacji rzeczy, które znajdują się w świecie przyrody oraz na związku zachowania się jednej rzeczy z zachowaniem się innej, a nie na badaniu ich wewnętrznej natury; zwracali oni uwagę raczej na przyczyny najbliższe aniżeli na 
formy substancjalne, a w szczególności uwzględniali te aspekty świata fizycznego, które można wyrazić w formie matematycznej ${ }^{1}$.

Siedemnastowieczna filozofia nauki nie była jednorodna. Metody dopiero się kształtowały, a wiele wybitnych umysłów formułowało swoje postulaty i prowadziło badania opierając się na wypracowanych przez siebie kryteriach. Należy pamiętać, że „Metodzie naukowej XVII w. nie można przypisywać jednego źródła. Nie została ona logicznie wypracowana przez jakiegokolwiek jednego filozofa, ani nie była całkowicie egzemplifikowana w jakichkolwiek jednych poszukiwaniach"2.

Istotny wpływ na filozofię XVII wieku oraz późniejszą wywarł Kartezjusz. Obok dualizmu psychofizycznego rozważanego przez myślicieli po dziś dzień, niekwestionowany jest wpływ jego metody ${ }^{3}$. Przytaczanie wątpienia metodycznego, pozwalającego na obalenie dotychczasowej wiedzy jako niepewnej (poparte krytyką nauki w formie, jaką miała przed Kartezjuszem), kryteriów jasności i wyraźności ${ }^{4}$ wskazujących twierdzenia prawdziwe czy też zalecenia postępowania od prawd oczywistych i prostych ku bardziej złożonym, dążenie do nauki geometrycznej, jest oczywistością, której pominięcie jest jednak niemożliwe.

Podczas gdy

Filarami nauki Kartezjusza były „jasno i wyraźnie” pojęcia formułowane jako prawa przyrody i stosownie do nich, a nie do dowodu eksperymentalnego kształtowały się jego teorie pomocnicze. Zasadniczo odbywało się to w drodze dedukcji z tych praw przyrody, a jeśli wiedza nie dostarczała potrzebnych materiałów, wówczas materiały te musiały być prowadzane za pomocą rozumowej dedukcji ${ }^{5}$,

wiele wybitnych umysłów epoki opowiadało się za nauką jako eksperymentalną. Spośród licznych myślicieli warto szczególnie wyróżnić dwóch: Francisa Bacona i Galileusza.

${ }^{1}$ A. C. Crombie, Nauka średniowieczna i początki nauki nowożytnej, t. 2, tłum. S. Łypacewicz, Warszawa 1960, s. 153.

2 A. R. Hall, Rewolucja naukowa 1500-1800, tłum. T. Zembrzuski, Warszawa 1966, s. 220.

${ }^{3}$ Por. Kartezjusz, Rozprawa o metodzie, tłum. T. Żeleński (Boy), Warszawa 1952, księga II.

${ }^{4}$ Por. R. Descartes, Medytacje o pierwszej filozofii, tłum. M. i K. Ajdukiewiczowie, S. Swieżawski, I. Dąmbska, Kęty 2001, s. 57.

${ }^{5}$ A. R. Hall, Rewolucja naukowa 1500-1800, s. 216. 
Bacon krytykował wiedzę opartą na autorytecie. Był otwartym przeciwnikiem arystotelizmu, dostrzegając jego wady i potępiając uczonych ślepo podążających za autorytetem Stagiryty, bez próby weryfikacji obowiązujących od starożytności poglądów. Jednocześnie nie negował on wartości współpracy wręcz przeciwnie, uważał ją za drogę do osiągania lepszych wyników, postulując stworzenie instytucji skupiającej uczonych ${ }^{6}$. Dostrzegał także utylitarny cel nauki, widząc w niej drogę do postępu i poprawy dobrobytu. Chociaż nie on pierwszy stawiał taki postulat ${ }^{7}$, podkreślenie wagi możliwości wykorzystywania nauki było jego ogromną zasługą. Łączył uznanie praktycznego wymiaru za cel nauki z ukształtowaniem jej jako systematycznego badania wiedzy, będącego skuteczniejszym od przypadkowych odkryć. Jak twierdził,

Prawdziwy zaś i właściwy cel nauk - to nic innego, jak wyposażenie życia ludzkiego w nowe wynalazki i środki. Olbrzymia wszakże większość ludzi nic z tego nie rozumie, lecz pracuje dla zarobku i wedle rutyny [...] ogół ludzi tak daleki jest od tego, ażeby postawić sobie za cel powiększenie skarbca nauk i umiejętności, że nawet $\mathrm{z}$ tego dorobku, który jest pod ręką, nic więcej nie biorą ani nie szukają ponad to, co mogą obrócić na swój zawodowy użytek lub co może im przynieść zysk materialny albo uznanie, albo inne tego rodzaju korzyści ${ }^{8}$.

Jednocześnie nie deprecjonował nauki jako teoretycznej. Eksperyment, czy osiągnięcia techniczne doceniał także za to, że potwierdzały (lub obalały) teorię. Skupiając się na wiedzy osiąganej dzięki eksperymentom, łącząc dane zmysłowe $\mathrm{z}$ wiedzą uzyskaną $\mathrm{z}$ doświadczenia ${ }^{9}$, Bacon jednakże zarazem nie doceniał roli matematyki w rozwoju nauki ${ }^{10}$. W ten sposób jego metoda była skuteczna w biologii, ale nie mogła być wystarczająca dla astronomii czy mechaniki.

Zalety metody Kartezjusza i Bacona w swej pracy zdawał się łączyć Galileusz. Chociaż ten wybitny naukowiec „Nie zbudował metodycznej filozofii nauki, [...] elementy takiej filozofii można wydobyć z jego dzieł"11. Łączył metodę abstrakcji, posługiwanie się dedukcją czy pracę na podstawie aksjo-

\footnotetext{
${ }^{6}$ A. Quinton, Bacon, [w:] Renaissance thinkers, Oxford 1993, s. 183.

${ }^{7}$ Więcej na ten temat: tamże, s. 198.

${ }^{8}$ F. Bacon, Novum Organum, tłum. J. Wikarjak, Poznań 1955, rozdz. Ks. I, r. LXXXI, s. 105106.

${ }^{9}$ M. Wiszniewski, Bacona metoda tłumaczenia natury, [w:] M. Wiszniewski, Bacona metoda tłumaczenia natury i inne pisma filozoficzne, Warszawa 1976, s. 135.

${ }^{10}$ A. R. Hall, Rewolucja naukowa 1500-1800, s. 200.

${ }^{11}$ Ibidem, s. 201.
} 
matów, środki matematyczne, z obserwacją. Eksperyment miał sprawdzać teorię. Obserwacja stanowiła dla nauki punkt wyjścia, pozwalała dostrzec problem, była także punktem dojścia - gdyż dobra teoria musiała zgadzać się z wynikami empirycznymi. Naturę postrzegał jednak jako opisywalną w sposób matematyczny ${ }^{12}$, zatem i teorie, modele zjawisk, miały być wyrażane $\mathrm{w}$ formie matematycznej ${ }^{13}$. Kładąc nacisk na prowadzenie pomiarów i matematykę, Galileusz łączył metodę eksperymentalną z przedstawianiem obserwacji w sposób matematyczny i ze sprawdzaniem uogólnionych hipotez w sposób ilościowy ${ }^{14}$.

Siedemnastowieczna filozofia nauki nie była monolitem. Wielu wybitnych autorów, spośród których trzech zostało wspomnianych w niniejszej pracy, tworzyło podstawy nowej metody naukowej. Krytykując opartą na autorytecie naukę poprzedzającą ich epokę, wprowadzali nowe spojrzenie na dążenie do prawdy. Pomimo rozbieżnych niekiedy poglądów poszczególnych myślicieli, dostrzec można dwie wyraźnie wyróżniające się tendencje: z jednej strony dążenie do nauki matematycznej, do wiedzy pewnej, z drugiej zaś postulowanie opierania się na obserwacji, na danych empirycznych.

Wiek XVII przyniósł przełom nie tylko w sferze nauk ścisłych i filozofii. Wypracowane w nich idee znalazły także swój oddźwięk w rozpoczynającej swą transformację ekonomii. Chociaż ogromnym przełomem, oddziałującym na tę naukę po dziś dzień, okazały się dopiero powstałe w drugiej połowie XVIII wieku Badania nad natura i przyczynami bogactwa narodów Adama Smitha, to jego teoria gospodarcza nie powstała w próżni - była również wynikiem twórczego przepracowania między innymi koncepcji poprzedzających jego dzieło o stulecie. Pomysły analogiczne do tych wyrażanych przez Smitha odnaleźć można już w przesiąkniętej duchem siedemnastowiecznej nauki pracy Dudley'a Northa.

Rozprawy o handlu ${ }^{15}$ początkowo wydane zostały anonimowo w 1691 roku, opatrzone (wówczas również niepodpisaną) Przedmową autorstwa brata autora głównego tekstu ${ }^{16}$. Same napisane stylem bardzo surowym,

12 A. C. Crombie, Nauka średniowieczna i poczatki nauki nowożytnej, s. 177.

${ }^{13}$ T. Sierotowicz, Galileusz, Kraków 2003, s. 44.

${ }_{14}$ A. C. Crombie, Nauka średniowieczna i początki nauki nowożytnej, s. 176.

${ }^{15}$ D. North, Rozprawy o handlu, [w:] Merkantylizm i początki szkoły klasycznej. Wybór pism ekonomicznych XVI i XVII wieku, wyboru dokonał E. Lipiński, przeł. C. Znamierowski, Kraków 1958, s. 747-778.

${ }^{16}$ Edward Lipiński (E. Lipiński, Merkantylizm i początki szkoły klasycznej, s. 733) twierdził, że pracę Dudley’a Northa Przedmową opatrzył Francis North, W. Letwin (W. Letwin, The au- 
zdradzającym dzieło praktyka, wiele zyskują dzięki Przedmowie, wyłuszczającej metodę naukową i zwracającej uwagę na nowatorski charakter tekstu oraz usprawiedliwiającej autora pracy.

Wyjątkowy duch tych zapomnianych przez lata rozpraw nie wynika jedynie z oryginalności zawartych w nich idei ekonomicznych - interesujący jest też sposób ich przedstawienia. Chociaż tworząc niezwykle krótki tekst Dudley North ani nie przedstawił, ani nie wykorzystał w pełni metody, warto podkreślić, tak, jak zrobił to autor Przedmowy, że

o wytwórczości i handlu traktuje się tutaj wedle innej miary, niż to się czyniło zazwyczaj dotychczas, a mianowicie filozoficznie [...] autor zaczyna energicznie od zasad bezspornie prawdziwych; i w ten sposób, posuwając się z jednakową starannością, dochodzi do pewnego sądu o najbardziej subtelnych dyskusjach i zagadnieniach dotyczących wytwórczości i handlu. Czyni to przy tym z dostateczną jasnością, sprowadza bowiem rzeczy do przypadków krańcowych $[\ldots]$ Tę metodę rozumowania wprowadzono wraz z nową filozofią $[\ldots]$ Te hipotezy nie dawały żadnej pewności; ale gdy zjawiła się doskonała dysertacja De Methode Kartezjusza, która znalazła tak wiele uznania i została przyjęta w naszych czasach, wszystkie takie chimery szybko się rozwiały i znikły. Stąd też wiedza w wielkiej mierze stała się mechanistyczna; słowa tego nie potrzebuję tłumaczyć szerzej jak zauważając, że znaczy ono tutaj tyle, co oparcie na jasnych i oczywistych prawdach ${ }^{17}$.

Dudley North opierał się na obserwacjach i doświadczeniu, opisywał rzeczywistość gospodarczą, analizując skutki poszczególnych sposobów postępowania. Jego praca, prowadząca do tez sugerujących postępowanie wolnorynkowe, starała się spełniać kryteria jasności i wyraźności. Bazował na uznanych powszechnie stwierdzeniach, wyprowadzając z nich konsekwencje dalekie od oczywistości, biorąc pod uwagę stan ówczesnej myśli ekonomicznej.

torship of Sir Dudley North's Discourses on Trade, „Economica”, New Series, Vol. 18, nr 69, luty 1951) natomiast, podobnie jak Jacob H. Hollander (J. C. Hollander, Introduction, [w:] D. North, Discourses upon Trade, The Online Library of Liberty, Liberty Fund, Indianapolis 2011 [na podstawie wydania Discourses upon Trade. A Reprint of Economic Tracts, The Johns Hopkins Press, Baltimore 1907]), dowodzą, że jej autorem był inny z trzech braci Northa Roger.

${ }^{17}$ R. North(?), Przedmowa, [w:] D. North, Rozprawy o handlu, s. 740-741. 
North opowiadał się za wolnością handlu ${ }^{18}$, krytykował monopole, sprzeciwiając się interwencjonizmowi oraz nie postrzegając gospodarki przede wszystkim z perspektywy przywozu i wywozu pieniądza. Inaczej niż merkantyliści, twierdził, iż gromadzenie pieniędzy i kruszców nie przyczynia się do wzrostu bogactwa ${ }^{19}$, gdyż zasoby naturalne, złoto i srebro (a zatem również pieniądz) to po prostu towary podlegające prawom rynku ${ }^{20}$. W rzeczywistości ludzie nie potrzebują pieniędzy - pragną tego, co mogą za nie kupić, prawdziwym bogactwem jest posiadanie nadwyżki dóbrr ${ }^{21}$, które można konsumować lub inwestować. Podobnie jak stulecie później Smith, Dudley North twierdził, że do działań rynkowych człowieka motywuje chęć zaspokojenia potrzeb i zdobycia pożądanych dóbr. Uznając pieniądz i kruszce za towar, dostrzegał powiązania między rynkami poszczególnych państw, a zarazem postrzegał gospodarkę jako system dążący do samoregulacji ${ }^{22}$.

Sam autor nie przyznawał się jawnie do stosowania kartezjańskiej metody. Dostrzeżenie jej w pracy nie jest oczywiste - ze względu także na specyficzny styl Dudley’a Northa. Podkreślenie nawiązań i inspiracji Kartezjuszem jest w dużej mierze zasługą Rogera Northa, zafascynowanego myślą twórcy Rozprawy o metodzie $e^{23}$.

Drugi z analizowanych $\mathrm{w}$ niniejszym tekście myślicieli - William Petty - był przedstawicielem kierunku, który w myśli ekonomicznej dominował od wieku XVI do połowy XVIII stulecia: merkantylizmu. Ze względu na długi okres występowania i licznych przedstawicieli, nie był to prąd jednorodny. Upraszczając i szukając „wspólnego mianownika” dla przedstawicieli tej szkoły należy zwrócić uwagę na podstawowe dla tego nurtu założenia ${ }^{24}$. Zdaniem merkantylistów całość bogactwa świata jest stała, a co za tym idzie, korzyść jednego kraju musi być stratą innego. Przekładało się to na ich po-

${ }^{18}$ J. R. McCulloch, Preface, [w:] J. R. McCulloch, A Select Collection of Early English Tracts on Commerce from the Originals of Mun, Roberts, North, and Others, The Online Library of Liberty, Liberty Fund, Indianapolis 2011 (na podstawie wydania A Select Collection of Early English Tracts on Commerce from the Originals of Mun, Roberts, North, and Others, with a Preface and Index, Political Economy Club, Londyn 1856), s. 14.

${ }^{19}$ D. North, Rozprawy o handlu, s. 762.

20 Tamże, s. 761.

${ }^{21}$ Tamże, s. 749, 759.

${ }^{22}$ E. Lipiński, Historia powszechnej myśli ekonomicznej do roku 1870, Warszawa 1968, s. 170.

${ }^{23}$ W. Letwin, The autorship of Sir Dudley North's Discourses on Trade, s. 52.

${ }^{24}$ H. Landreth, D. C. Collander, Historia myśli ekonomicznej, przeł. A. Szeworski, Warszawa 1998, s. 73-84, E. Lipiński Lipiński, Historia powszechnej myśli ekonomicznej do roku 1870, s. $98-126$. 
glądy dotyczące handlu międzynarodowego. Należało zachęcać do eksportu i zniechęcać do importu ${ }^{25}$, by kruszec, waluta, spływały do kraju - w ich przekonaniu to czynniki pieniężne świadczą o rozwoju gospodarczym. Dostrzegali oni konflikt między interesami prywatnymi a dobrem ogółu, zatem zadaniem rządu było budowanie takich mechanizmów, by dążenia ludzi służyły korzyściom publicznym. Opowiadali się za interwencjonizmem i regulacjami, w szczególności dotyczącymi bicia monety i obrotu handlowego.

Nie wszystkie jednak ich tezy sprzeczne były z poglądami współczesnego im Dudley’a Northa czy późniejszych fizjokratów i liberałów. Podzielali z nimi choćby przekonanie o egoistycznej naturze jednostek pragnących działać dla własnej korzyści. Późni przedstawiciele nurtu merkantylistycznego dostrzegali nawet wady interwencjonizmu, wciąż jednak uznając produkcję za cel działalności gospodarczej. Jak później fizjokraci, przyrównywali ekonomię do nauk ścisłych, pragnąc przenieść ich podstawy do nauk społecznych. Twierdzili, że prawa gospodarcze można odkrywać w taki sam sposób (posługując się odpowiednimi metodami) jak prawa przyrody. Wyprowadzali z tej tezy jednakże wniosek skrajnie odmienny od poglądów fizjokratów. Podczas gdy ci ostatni zalecali leseferyzm, merkantyliści, dostrzegając przyczynowość mechaniczną w gospodarce postulowali politykę interwencjonistyczną.

Wśród myślicieli wyrażających poglądy będące typowymi dla merkantylizmu znajdował się również William Petty. W tekstach poświęconych ekonomii opowiadał się on za regulacjami państwowymi, podkreślając rolę podatków i wydatków publicznych. Te pierwsze uznawał za sprawiedliwe szczególnie, jeżeli są równe dla wszystkich. Dzięki nim sfinansować można szeroko zakrojony (jak na ówczesne czasy) obszar wydatków, które, zdaniem myśliciela, powinny być pokrywane przez państwo ${ }^{26}$ : obok wydatków na obronę, wymiar sprawiedliwości, edukację czy drogi publiczne i mosty wymieniał on także wystawne utrzymanie urzędników (by podkreślać wagę ich zawodu), utrzymanie sierot, dzieci porzuconych i osób niedołężnych, a także zasiłki dla bezrobotnych - by nie żebrali na ulicach. Inaczej niż później Smith, Petty nie krytykował monopolu - dostrzegał nawet jego pozytywne aspekty ${ }^{27} \mathrm{w}$ pewnych sytuacjach.

\footnotetext{
${ }^{25}$ Por. T. Mun, Bogactwo Anglii w handlu zagranicznym, [w:] Merkantylizm i początki szkoły klasycznej, s. 137.

${ }^{26}$ W. Petty, Traktat o podatkach i daninach, [w:] Merkantylizm i początki szkoły klasycznej, s. $445-448$.

${ }^{27}$ Tamże, s. 523-528.
} 
Wkład, jaki ten siedemnastowieczny myśliciel wniósł do nauki wykracza poza rozważania dotyczące monet i podatków. Realizując ideały nauki empirycznej, matematycznej, opartej na faktach, Petty wprowadził i wykorzystał w swych pracach podstawy nauki, bez której nie tylko współczesna ekonomia, ale i wiele innych dziedzin nie mogłoby zaistnieć - został jednym z (obok Johna Graunta ${ }^{28}$ ) twórców statystyki.

Jedno z najsławniejszych dzieł Petty'ego - Anatomia polityczna Irlandii, tworzone, gdy stacjonował w tym kraju jako lekarz wojskowy - zawiera elementy statystyki. Opierając się na, niezwykle przecież ubogich, danych, Petty starał się katalogować, zapisywać oraz szacować liczbę ludności ${ }^{29}$, czy ilość zakładów produkcyjnych. Rozważał także koszta, jakie trzeba by ponieść na utrzymanie niektórych grup społecznych. Chociaż jego obliczenia były bardzo proste i posługiwały się, niedopuszczalnymi z dzisiejszego punktu widzenia, uogólnieniami, wniosły do nauki nową metodę, intensywnie rozwijaną przez następców tego myśliciela. Metodę, bez której nie można wyobrazić sobie choćby dzisiejszej ekonometrii.

Wypracowanie przez Petty'ego metody statystycznej stanowiło ogromny przełom dla nauki. Dowodziło jednak zarazem, że uczony ten osadzony był głęboko w „duchu” swej epoki i, realizując jej ideały, wprowadził do nauki niezwykle odkrywcze narzędzie. Wpływ na jego poglądy wywarło wiele największych umysłów epoki. Sam autor Anatomii politycznej Irlandii dołączył do ich wielkich teorii swój niebagatelny wkład.

Polityczne poglądy tego filozofa zostały poniekąd ukształtowane przez myśl Thomasa Hobbesa. Ci wielcy myśliciele studiowali razem anatomię w Paryżu i Petty pozostał pod ogromnym wrażeniem swego towarzysza nauk ${ }^{30}$. Podziwiał nie tylko samego filozofa i jego geniusz, uznanie Petty’ego zdobyło także najsławniejsze $\mathrm{z}$ dzieł Hobbesa - Lewiatan. Z jednej strony ukształtowało to poglądy polityczne ekonomisty, z drugiej zaś wywarło wpływ na całą jego pracę, formując metodę naukową:

\footnotetext{
${ }^{28}$ Więcej na ten temat: F. M. Williams, The Origin and Development of Modern Trade Statistics, „Quarterly Publications of the American Statistical Association”, vol. 17, nr 134, czerwiec 1921.

${ }^{29}$ Por. W. Petty, Anatomia polityczna Irlandii, [w:] Merkantylizm i początki szkoły klasycz$n e j \ldots$.

${ }^{30}$ Więcej na ten temat w: Q. Skinner, Thomas Hobbes and His Disciples in France and England, "Comparative Studies in Society and History”, Cambridge University Press, Vol. 8, nr 2, styczeń 1966.
} 
Petty zgadzał się z Hobbesem, że jego najbardziej epokową i owocna sugestią był pogląd, iż nauka polityczna może być skonstruowana przy użyciu metody analogicznej do dowodu 'geometrycznego ${ }^{31}$.

Takie spojrzenie, skupienie się na ideale "geometrycznej nauki”, tak charakterystyczne przecież dla siedemnastowiecznej myśli budującej naukę po części na wzór matematycznej pewności, zaowocowało wypracowaniem przełomowego podejścia do liczb, pozwalającego lepiej wykorzystywać obserwacje i wyciągać z nich wnioski.

William Petty był jednym z twórców narzędzia, które pozwoliło na opracowywanie i pełniejsze wykorzystywanie danych empirycznych. Tak ujęta statystyka stała się logicznym następstwem postulatów nauki eksperymentalnej, które przecież obecne były w siedemnastowiecznej filozofii nauki. Jak zauważył Charles H. Hull:

Szczególne zamiłowanie Petty’ego do metody statystycznej jest wynikiem, jak uważam, wpływu Bacona, który był dominujący wśród naukowych współpracowników w świeżo powstałym Royal Society. Jak wszyscy zwolennicy Bacona, wierzył on w przydatność obserwacji i, w związku z tym, w jednorodność natury oraz z pewnością oczekiwał czasu, kiedy precyzyjna wiedza o świecie zewnętrznym położy trwałe fundamenty pod wynalazki ${ }^{32}$.

William Petty i Dudley North czerpali z dwóch różnych źródeł siedemnastowiecznej teorii nauki: pierwszy inspirował się Hobbesem i Baconem, działając w paradygmacie merkantylistycznej ekonomii, tworząc statystykę, by w sposób matematyczny opracowywać obserwacje przydatne dla nauki. Drugi z nich napisał swe krótkie dzieło opierając się na wyrażonych przez Kartezjusza zaleceniach podążania od prawd oczywistych do bardziej złożonych, nie pomijając zarazem etapu obserwacji - jako dla praktyka było to dla Northa niezwykle cenne źródło wiedzy i inspiracji. Ich koncepcje naukowe wyrosły na podwalinach siedemnastowiecznych ideałów nauki: Kartezjańską metodę, Baconowski empiryzm czy Hobbesowskie (chociaż wielu innych filozofów wyrażało podobne poglądy) dążenie do stworzenia nauki „geometrycznej" - nawet w sferze nauk społecznych. Wpisując się w nurt epoki, William Petty stworzył podstawy statystyki (wciąż bardzo niedoskonałej),

\footnotetext{
${ }^{31}$ Tamże, s. 161, tłumaczenie własne.

32 C. H. Hull, Petty's Place in the History of Economic Theory, „The Quarterly Journal of Economics", Oxford University Press, Vol. 14, nr 3, maj, 1900, s. 314, tłumaczenie własne.
} 
jednocześnie można stwierdzić, że inspirując się myślą społeczną Hobbes’a oraz dążąc do popartej obserwacją i danymi liczbowymi nauki o gospodarce, „Petty był w pewien sposób prekursorem Adama Smitha, 'twórcy ekonomii politycznej”" 33 . Dudley North zaś przedstawił poglądy ekonomiczne, które, chociaż na długo zapomniane, stanowiły niezwykle oryginalną antycypację idei szkoły klasycznej w ekonomii. Obaj budowali teorie w charakterze niemal osiemnastowieczne, czerpiąc inspirację z siedemnastowiecznej filozofii nauki.

\section{Abstract \\ Seventeenth-century philosophy as an inspiration for the precursors of the classical economic thought}

Keywords: Dudley North, William Petty, statistics, seventeenth-century philosophy of science

The article presents the economical views of Dudley North and William Petty. At the same time it indicates that the seventeenth-century philosophical ideas - the Method created by Descartes, aiming at constructing a geometrical and mathematical sciences or Hobbes' philosophy - were an inspiration to the mentioned thinkers, allowing them to develop an innovative science. North's original economical concept can be compared to the later concepts of liberal economy. Statistics that was created by Petty, basing on the Baconian ideals of sciences, is still one of the bases for development of economic science.

${ }^{33}$ Tamże, s. 338, tłumaczenie własne. 